\title{
Ecological partitioning of three Columbidae species in Northern Paraná, Southern Brazil
}

\author{
Priscila Montes Fontoura ${ }^{1,3}$ \& Mário Luis Orsi ${ }^{2}$ \\ ${ }^{1}$ Programa de Pós-graduação em Ciências Biológicas, Universidade Estadual de Londrina - UEL, \\ CP 10011, CEP 86057-970, Londrina, PR, Brazil \\ ${ }^{2}$ Departamento de Biologia Animal e Vegetal, Universidade Estadual de Londrina - UEL, \\ CP 10011, CEP 86057-970, Londrina, PR, Brazil \\ ${ }^{3}$ Corresponding author: Priscila Montes Fontoura, e-mail: primontes@yahoo.com.br
}

FONTOURA, P.M. \& ORSI, M.L. Ecological partitioning of three Columbidae species in Northern Paraná, Southern Brazil. Biota Neotrop. 13(3) http://www.biotaneotropica.org.br/v13n3/en/ abstract?article+bn00913032013

Abstract: Three species of Columbidae (Columbina talpacoti, Columbina picui and Zenaida auriculata) were studied in Londrina, Northern Paraná (Brazil), with the aim of analyzing which foraging and habitat factors contribute to their ecological partitioning. The study was conducted over one year in three different areas (urban, rural and pasture). We made monthly observations of the foraging strategies used by the species and the habitats they selected. Possible variations in availability of resources over the twelve months of the study did not influence the type of foraging used by the three species. Significant differences between the foraging strategies used by the species were observed in relation to the foraging site, specifically the foraging substrate. Soil, grass and paving were the foraging substrates that were most used by all three species, indicating that they are ground-foraging birds. Differences in the time spent in the foraging areas were significant between species; Z. auriculata remained in the foraging area for the longest time, often foraging in a group, suggesting a possible adaptation of this species in order to obtain a greater amount of resources. Adapting to anthropological environments without continuous forest cover could be one of factors that the most influential in the selection of habitat by the three species of Columbidae. Principal Components Analysis (PCA) showed differences between the proportions of herbaceous and gramineae plants, paving, plantations and shrubs in the habitats selected by each species. We also concluded that differences in the time spent in the foraging areas and between foraging substrates are factors contributing to the ecological separation of the three species and therefore allowing their coexistence in the region.

Keywords: Columbina picui, Columbina talpacoti, foraging strategies, habitat selection, Zenaida auriculata.

FONTOURA, P.M. \& ORSI, M.L. Repartição ecológica de três espécies de Columbidae no Norte do estado do Paraná, Sul do Brasil. Biota Neotrop. 13(3) http://www.biotaneotropica.org.br/v13n3/en/ abstract?article+bn00913032013

Resumo: Três espécies de Columbidae (Columbina talpacoti, Columbina picui e Zenaida auriculata) foram estudadas em Londrina, Norte do Paraná (Brasil), com o intuito de analisar quais os fatores de forrageio e hábitat contribuem para a repartição ecológica dessas espécies. O estudo foi conduzido durante um ano em três áreas distintas (urbana, rural e de pastagem). Nós observamos mensalmente as estratégias de forrageio utilizadas pelas espécies e o hábitat que elas selecionam. Possíveis variações na disponibilidade de recursos ao longo dos doze meses de estudo não influenciaram no tipo de forrageio utilizado pelas três espécies. Diferenças significativas entre as estratégias de forrageio utilizadas pelas espécies foram observadas em relação ao local de forrageio, mais especificamente em relação ao substrato de forrageio. Solo, grama e pavimento foram os substratos de forrageio mais utilizados pelas três espécies, indicando que elas são espécies forrageadoras de solo. Diferenças entre o tempo de permanência na área de forrageio foram significativas entre as espécies; e Z. auriculata foi a espécie que se manteve por mais tempo na área de forrageio e frequentemente forrageava em grupo, sugerindo uma possível adaptação da espécie em relação a obtenção de uma quantidade maior de recursos. Adaptação a ambientes antrópicos e sem cobertura vegetal contínua pode ser uns dos fatores de maior influência no hábitat que as três espécies de Columbidae selecionam. Análises de Componentes Principais (ACP) mostraram diferenças entre as proporções de herbáceas e gramíneas, pavimento, plantações e arbustos no hábitat selecionado por cada uma das espécies. Nós concluímos também que diferenças entre o tempo de permanência na área de forrageio e diferenças entre o substrato de forrageio são fatores que contribuem para separação ecológica e permitem a coexistência das três espécies na região.

Palavras-chave: Columbina picui, Columbina talpacoti, estratégias de forrageio, seleção de hábitat, Zenaida auriculata. 


\section{Introduction}

Studies of foraging behavior are a useful tool in determining how birds use their habitat; they also enable environmental features that might influence bird populations to be identified (Cueto \& Casenave 2002). Traits such as foraging height, position, substrate foraging and patterns that relate variables of foraging behavior with habitat use are commonly investigated and may indicate dimensions which differentiate species (Wiens 1989) according to their use of resources and patterns of trophic niches. Resource availability is another factor to be considered in foraging studies, given that the quantity of food items can vary seasonally within a habitat.

Resource factors and conditions that involve spatial and temporal separation in the environment can contribute to the differentiation of niches between ecologically similar species that use the same resources (Begon et al. 2006). Furthermore, related species often differ in their habitat and/or habitat dimensions and thus avoid competition with each other (MacArthur \& Levins 1964). Habitat selection is a hierarchical process when considered in relation to behavioral responses, which might result in a disproportionate use of habitats in order to influence the survival and fitness of individuals (Hutto 1985, Block \& Brennan 1993, Jones 2001).

Columbina talpacoti (Temminck, 1811), Columbina picui (Temminck, 1813) and Zenaida auriculata (Des Murs, 1847) belong to the family Columbidae; their similarities include that they are all considered grassland species (Sick 1997) and have a granivorous diet (Baptista et al. 1997). The two Columbina species also have a similar length of approximately $16.5 \mathrm{~cm}$ (Sick 1997) and weight of $47 \mathrm{~g}$ (Dunning 2008), whereas Z. auriculata has a length of $21 \mathrm{~cm}$ (Sick 1997) and weight of $136 \mathrm{~g}$ (Dunning 2008). They are all distributed throughout most of Brazil and are classified as common throughout the year based on studies conducted in Londrina (Westcott et al. 2002, Lopes \& Anjos 2006). Populations of Z. auriculata have increased in Argentina and in the state of São Paulo (Brazil) since the mechanization of agriculture that has created landscapes with a large availability of food (Ranvaud \& Bucher 2006). Although Z. auriculata is present at a higher population density when compared to the other species (P.M. Fontoura \& M.L. Orsi, unpublished data), the three species are native and coexist in the study region.

Ecological mechanisms such as morphological divergence, behavior or even the differential use of food resources and resources in space could be evolutionary responses in the competition between species (Krebs 1985). This study investigated strategies used in foraging behavior and habitat selection by the three species that were the targets of this study, with the aim of: 1) evaluating the foraging strategies used by Z. auriculata, C. talpacoti and C. picui; 2 ) assessing the influence of temporal gradients on the kind of foraging used by species; 3 ) analyzing the habitats they select within the environment; and 4) relating the corresponding factors to the components of foraging and habitat and the ecological partitioning of these similar species.

\section{Material and Methods}

\section{Study area}

Londrina $\left(23^{\circ} 17^{\prime} 32^{\prime \prime} \mathrm{S}\right.$ and $\left.51^{\circ} 10^{\prime} 23^{\prime \prime} \mathrm{W}\right)$ is a city located in Paraná State North, South Brazil. According to the Monitoring System of Agroclimatic Paraná (Instituto... 2013), the city has a climate classified as subtropical humid, the mean annual temperature is $21^{\circ} \mathrm{C}$ and annual precipitation is around $1600 \mathrm{~mm}$, varying between $53 \mathrm{~mm}$ in the driest month (August) and $219 \mathrm{~mm}$ in the rainiest month (January). Atlantic Forest is a dominant biome in the region (Fundação... \& Instituto... 2009).

The study was conducted in three areas commonly used by the species in Londrina. Area 1 is an urban area located on the outskirts of the city of Londrina, containing (percentages are approximate) residential homes $(60 \%)$, empty lots $(20 \%)$, paved streets $(15 \%)$, and trees and gardens $(5 \%)$. Area 2 is an agricultural area located in the rural area of Londrina characterized by plantations ( $80 \%)$, edge of secondary forest $(10 \%)$, bare soil (5\%) and built-up area $(5 \%)$. Finally, the third area is an area of pasture located in a rural zone, containing grass pasture $(65 \%)$, regenerating forest (15\%), edge of secondary forest $(10 \%)$ and built-up area (10\%).

\section{Foraging behavior and habitat selection}

Sampling was undertaken from August 2011 to July 2012, with monthly observations being made to collect foraging data and characterize the habitats of the three species involved in this study. Each of the three study areas was visited two days per month during the study period; sampling was begun two hours after sunrise. The daily observation time was two hours, totaling 48 hours of sampling effort for each area over the twelve months of study. A transect of 2,000 $\mathrm{m}$ was established in each area and walked by the observer on each day of observation. Direct observations of the foraging behavior of the species were recorded using the method of focal animal sampling (Altmann 1974), in which the foraging strategies of a selected individual were counted after an initial five seconds of contact with the species, during which time the individual could become accustomed to being observed. In order to reduce any pseudoreplication as a result of the autocorrelation of the foraging samples and to guarantee independence of the data, observations were separated by an interval of five minutes and only the initial foraging behavior of the individual was recorded (Hejl et al. 1990). When more than one species was presented to the observer, preference was given to observing the species for which fewer records had been made up to that point (Volpato \& Anjos 2001).

The foraging strategies were categorized according to the system proposed by Remsen \& Robinson (1990) for the feeding behavior of soil birds (with adaptations): 1) type of foraging or attack behavior to capture food: glean (to pick food from a nearby substrate), lunge (bird moves up to the food item), sally (fly from a perch to attack a food item), probe (insert the beak into cracks or holes in the substrate to capture hidden food) and flake (removing the loose substrate with beak movements); 2) the foraging site, classified according to the foraging substrate: soil, branch, air, grass or paving (including any type of flooring such as sidewalk and asphalt); 3) vertical position, i.e. the estimated height of the bird relative to the ground; 4) food item, when it was possible to observe this; 5) the time each bird spent at the foraging site, considered to be the area within a radius of $2 \mathrm{~m}$ from the point where the individual was first observed (Lopes et al. 2006); and 6) agonistic behavior: intraspecific or interspecific.

In parallel with sampling and observations of foraging behavior and between periods of recording the foraging strategies, habitat selection by the species was characterized according to the methodology of Marra \& Remsen (1997), with adaptations. Based on the physical characteristics of the environment and structure of the vegetation, ten environmental variables were discriminated (shown in Table 1). Information concerning environmental variables was collected within a radius of $10 \mathrm{~m}$ from the point where the individual was initially observed, and each detection was considered as a sample.

\section{Data analysis}

A two-way analysis of variance (ANOVA) $(p<0.05)$ was used to determine whether there were any differences between the species 
in relation to the five type of foraging used over the 12 months of study. A G-test was used to determine differences for the species in respect of the strategies related to type of foraging, foraging site and food item. Vertical position and time are quantitative variables and were therefore analyzed using a Kruskal-Wallis test, and agonistic behavior strategy was analyzed based on frequency of occurrence. A Principal Components Analysis (PCA) was performed both for the total data and separately for each species, with the aim of identifying the most important environmental variables in the habitat selected by the species. The axes were retained for interpretation of the PCA data and the highest values of the eigenvectors of the principal axes were considered as being the most representative in the analysis.

\section{Results}

A total of 381 observations of foraging behavior were obtained for the three species during the twelve-month study period, of which 53 observations were for C. talpacoti, 48 for C. picui and 280 for Z. auriculata. No significant temporal differences were found in the type of foraging used during the study by C. talpacoti $\left(\mathrm{F}_{4,36}=0.614\right.$, $p=0.974), C$. picui $\left(\mathrm{F}_{4,36}=0.434, p=0.999\right)$ or $Z$. auriculata $\left(\mathrm{F}_{4,36}=1.181, p=0.212\right)$. However, all species preferentially used foraging by glean (Table 2), and therefore no significant differences in the type of foraging used were found between them $(\mathrm{G}=8.62$, $\mathrm{df}=8, p=0.38$ ). Columbina talpacoti and C. picui were observed foraging on soil, branches, grass and paving, whereas $Z$. auriculata was recorded on all foraging substrates (Table 2). Significant differences were found between the foraging sites used by the species $(\mathrm{G}=18.4, \mathrm{df}=8, p=0.019)$. The specific food items consumed by a species could be observed in $19.7 \%$ of the total foraging samples. Species did not differ in the type of ingested food $(\mathrm{G}=0.97, \mathrm{df}=2$, $p=0.615$ ) and seed was the preferred food item, with a preference of at least $95 \%$ (Table 2). No significant differences were observed in the vertical position of the foraging of C. talpacoti, C. picui and Z. auriculata $(\mathrm{H}=0.034, p=0.98)$, but the species differed in the time spent in the foraging areas $(\mathrm{H}=80.9, p<0.001)$ (Figure 1) and $Z$. auriculata remained significantly longer at a foraging site than the two other species (Mann-Whitney pairwise comparisons, $p<0.001$ ). Agonistic behavior was observed in $1.05 \%$ of the total foraging samples, with all occurrences being for $Z$. auriculata. This represents a $1.43 \%$ occurrence frequency of intraspecific behavior for this species.
Of the environmental variables that were representative of each species (Table 3), four were common to the three species in the following order: absence of leaf litter, buildings up to $10 \%$, bare soil up to $10 \%$ and the absence of large trees $(\mathrm{CBH}>30 \mathrm{~cm})$. Paving of more than $10 \%$ and an absence of shrubs were also important categories for C. talpacoti and C. picui. Considering the PCA of all species together, Principal Component 1 (one axis) explained $41 \%$ of the variance and was influenced by the absence of plantations, buildings up to $10 \%$ and paving up to $10 \%$. Principal Component 2 (axis 2) explained $20 \%$ of the data variance, and was influenced by the absence of leaf litter and absence of shrubs (Figure 2). Principal Component 3 (axis 3 ) explained $14 \%$ of the variance and was influenced by the variables of herbaceous and gramineae up to $10 \%$, bare soil up to $10 \%$ and the absence of large trees (Figure 3). The three Principal Components together explained $75 \%$ of the variance for the obtained data.

\section{Discussion}

The three related study species are all adapted to anthropic environments without continuous forestation cover in Londrina. However, population levels of Z. auriculata have increased in South America, particularly in the states of São Paulo and Paraná, where agriculture has expanded over the years and replaced previously forested areas (Bucher \& Ranvaud 2006). According to our results, the three species differ in the selection of environmental variables relating to the time spent in foraging areas and the foraging substrate, these being factors that have contributed to the ecological separation of the three species in the study region.

Although there was possibly a seasonality of resources during the twelve months of the study, mainly in the rural area, where cultivated grains were abundant during planting and harvesting and scarce at other times of the year, the analyses of the foraging strategies showed that the three species most frequently used gleaning. According to Remsen \& Robinson (1990), many bird studies demonstrate this pattern of food capture, since gleaning food is presumably the least costly activity in terms of energy expenditure to the individual. A similar result was found by Volpato \& Anjos (2001), in which glean was the dominant strategy of $Z$. auriculata and C. picui. Only items consumed near to the observer could be identified. The three study species readily swallow their food, making it difficult to assess food items consumed by individuals from direct observation. Seeds were

Table 1. Environmental variables converted to a scale of 0,1 or 2 in order to characterize the habitat selected by $C$. talpacoti, $C$. picui and Z. auriculata during the period August 2011 to July 2012 in Northern Paraná, Southern Brazil.

\begin{tabular}{ll}
\hline \multicolumn{1}{c}{ Variable } & \multicolumn{1}{c}{ Classification } \\
$\begin{array}{l}\text { leaf-litter, bare soil, shrubs, herbaceous/gramineae, } \\
\text { buildings, paving and plantations }\end{array}$ & $(0)$ absence, (1) presence up to $10 \%$ and $(2)$ presence more than $10 \%$ in area \\
$\begin{array}{l}\text { spacing of shrubs } \\
\text { large trees }(\mathrm{CBH}>30 \mathrm{~cm})^{*}\end{array}$ & $(0)$ absence, $(1)$ distance of more than $1 \mathrm{~m}$ and $(2)$ distance up to $1 \mathrm{~m}$ among the shrubs \\
spacing of large trees & $(0)$ absence, $(1)$ distance of more than $3 \mathrm{~m}$ and $(2)$ distance up to 3 m among trees \\
\hline
\end{tabular}

(*) $\mathrm{CBH}$ - circumference at breast height.

Table 2. Total number of records obtained in relation to types of foraging, foraging sites and food items for C. talpacoti, C. picui and Z. auriculata during the period August 2011 to July 2012 in Northern Paraná, Southern Brazil.

\begin{tabular}{|c|c|c|c|c|c|c|c|c|c|c|c|c|}
\hline \multirow{2}{*}{ Species } & \multicolumn{5}{|c|}{ Type of foraging } & \multicolumn{5}{|c|}{ Foraging site } & \multicolumn{2}{|c|}{ Food taken } \\
\hline & Glean & Lunge & Sally & Probe & Flake & Soil & Branch & Air & Grass & Paving & Seed & Arthropod \\
\hline Columbina talpacoti & 49 & 3 & 0 & 1 & 0 & 26 & 2 & 0 & 14 & 11 & 7 & 0 \\
\hline Columbina picui & 45 & 2 & 0 & 0 & 1 & 26 & 1 & 0 & 10 & 11 & 4 & 0 \\
\hline Zenaida auriculata & 241 & 28 & 4 & 5 & 2 & 158 & 6 & 2 & 23 & 91 & 61 & 3 \\
\hline
\end{tabular}


(A)

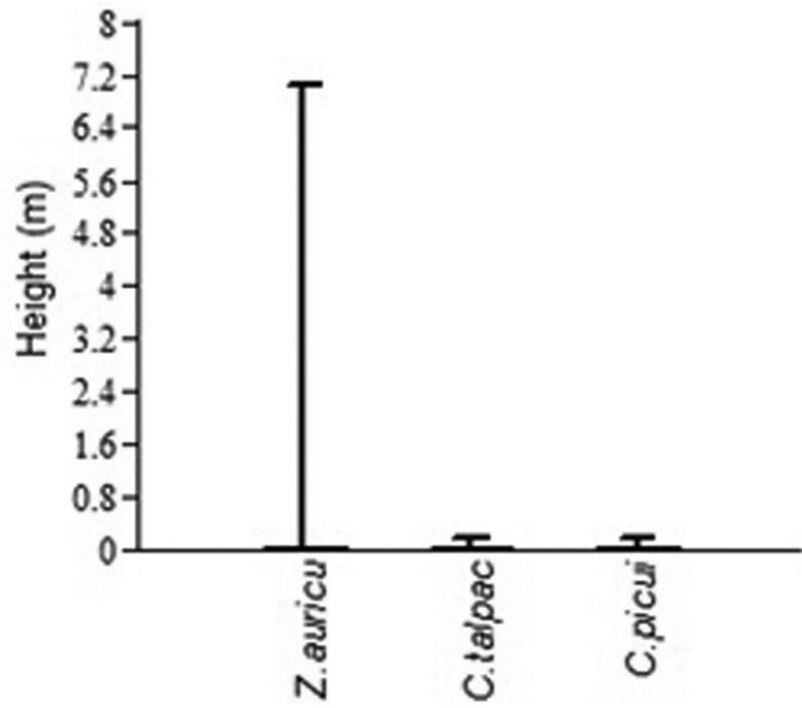

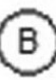

Figure 1. Box plots representing the median of foraging strategies of Columbina talpacoti, Columbina picui and Zenaida auriculata recorded during the period August 2011 to July 2012 in Northern Paraná, Southern Brazil: A) Vertical position - height of foraging in relation to the ground, and B) time spent in foraging areas.

Table 3. Percentage of concentrated variance on each axis retained and variables that most influenced the ordering of points (eigenvector values) from the PCA, according to habitat selected by C. talpacoti, C. picui and Z. auriculata during the period August 2011 to July 2012 in Northern Paraná, Southern Brazil.

\begin{tabular}{|c|c|c|c|}
\hline Species (n) & Axis & Variance $(\%)$ & Variable (eigenvector) \\
\hline \multirow{3}{*}{$\begin{array}{l}\text { Columbina talpacoti } \\
\text { (73) }\end{array}$} & 1 & 40 & Absence of leaf-litter (-0.44); paving more than $10 \%(0.52)$; buildings up to $10 \%(0.42)$ \\
\hline & 2 & 25 & Bare soil up to $10 \%(-0.63)$; herbaceous and gramineae more than $10 \%(-0.30)$ \\
\hline & 3 & 12 & Absence of large trees $(0.45)$; absence of shrubs $(-0.38)$ \\
\hline \multirow{3}{*}{$\begin{array}{l}\text { Columbina picui } \\
\text { (66) }\end{array}$} & 1 & 41 & Absence of leaf-litter $(-0.45)$; paving more than $10 \%(0.49)$; buildings up to $10 \%(0.42)$ \\
\hline & 2 & 25 & Bare soil up to $10 \%(-0.52)$; absence of large trees $(0.42)$ \\
\hline & 3 & 11 & Absence of shrubs $(-0.44)$ \\
\hline \multirow[t]{3}{*}{$\begin{array}{l}\text { Zenaida auriculata } \\
(321)\end{array}$} & 1 & 48 & $\begin{array}{l}\text { Bare soil up to } 10 \%(0.34) \text {; absence of plantations }(0.57) \text {; absence of paving }(-0.53) \text {; } \\
\text { buildings up to } 10 \%(-0.46)\end{array}$ \\
\hline & 2 & 15 & $\begin{array}{l}\text { Absence of large trees }(-0.40) \text {; herbaceous and gramineae up to } 10 \%(0.46) \text {; absence of } \\
\text { leaf-litter }(0.43)\end{array}$ \\
\hline & 3 & 13 & $* * *$ \\
\hline
\end{tabular}

$(* * *)$ did not show representative variable

the food item preferred by species in this study; this was also the case in studies of $C$. talpacoti in the Venezuela savanna (Pérez \& Bulla 2000) and Central Brazil (Cintra et al. 1990), and of Z. auriculata in southeastern Brazil (Ranvaud et al. 2001), in southern Brazil (Cândido-Junior et al. 2008), in northwest Venezuela (Chacín \& Calchi 2007) and in Argentina (Murton et al. 1974). Moreover, $Z$. auriculata can be considered to be legitimate seed dispersers (Bucher \& Bocco 2009).

The species showed differences in relation to foraging site, specifically in relation to the type of foraging substrate. Soil, grass and pavement were to different extents the foraging sites most used by the three species (Table 2), indicating that they are ground-foraging birds i.e. that they feed mainly on the ground where the vertical position is zero. For urban birds, foraging on the ground offers advantages over other strata because of the increased visibility afforded by lawns, which increases the probability of detecting and escaping predators (Beissinger \& Osborne 1982); in general, there are more seeds on the ground under trees (Milesi et al. 2008).

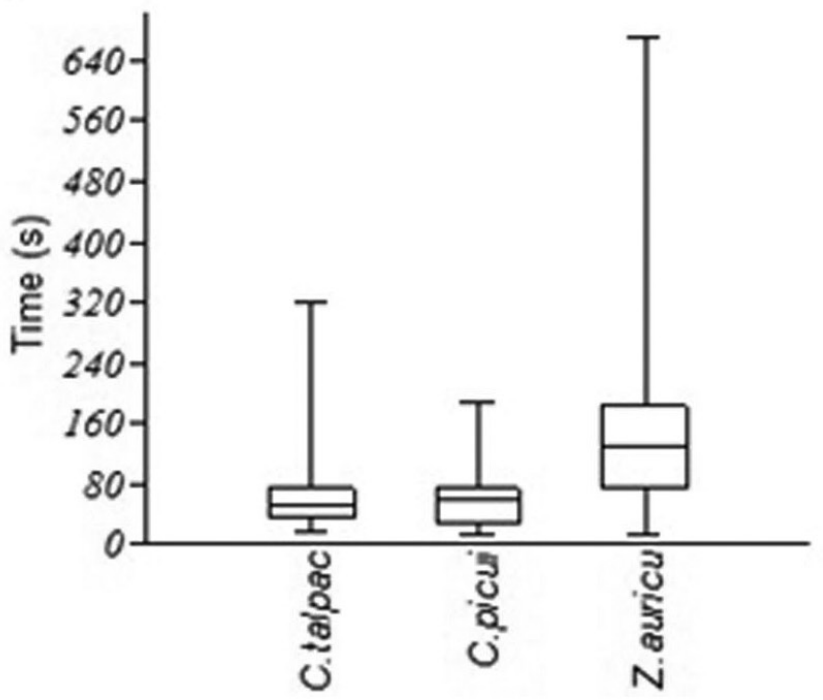




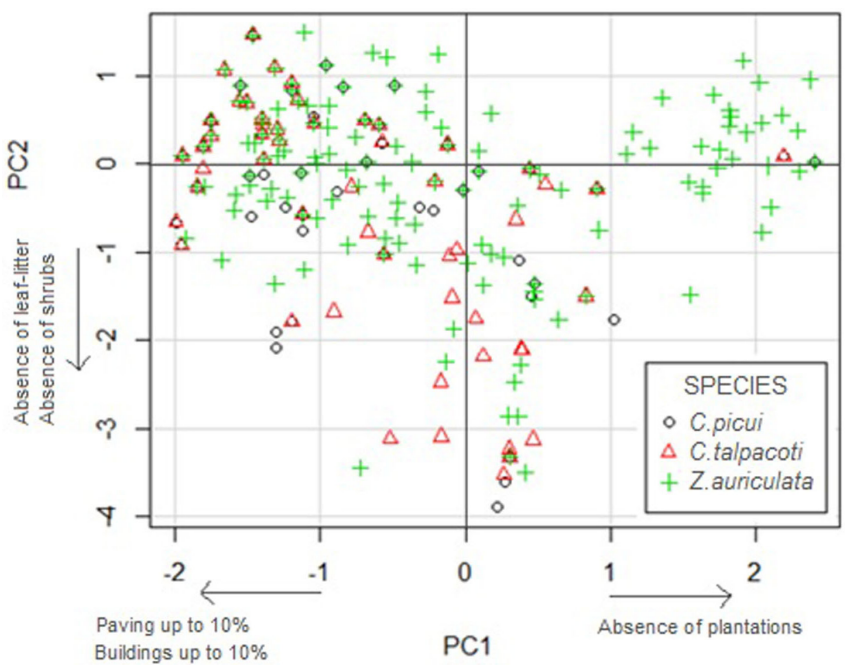

Figure 2. Ordination diagram of points produced by Principal Components Analysis (PCA) showing the distribution of C. talpacoti, C. picui and Z. auriculata on the first two components, according to the environmental variables selected by three species during the period August 2011 to July 2012 in Northern Paraná, Southern Brazil.

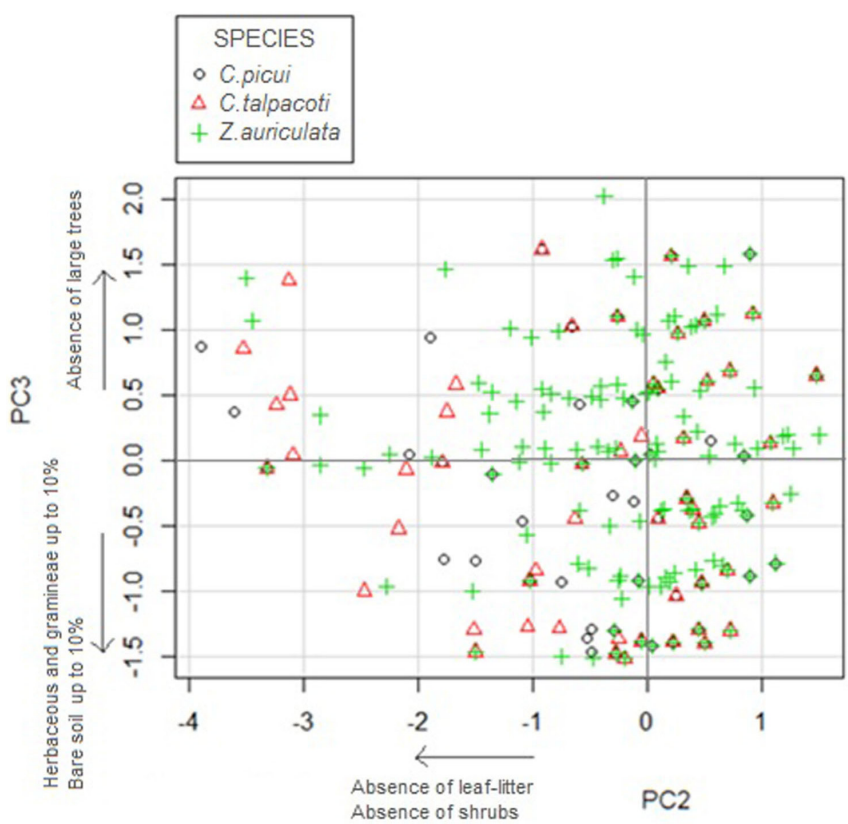

Figure 3. Ordination diagram of points produced by Principal Components Analysis (PCA), showing the distribution of C. talpacoti, C. picui and Z. auriculata on components 2 and 3 , according to the environmental variables selected by three species during the period August 2011 to July 2012 in Northern Paraná, Southern Brazil.

number of individuals in a foraging group of Columbina passerina (Linnaeus, 1758) and Leptotila verreauxi Bonaparte, 1855 in Costa Rica, allowed each individual to spend their time more profitably in the obtaining of resources and, consequently, possibly resulted in a decrease in vigilance behavior (Burger 1992). Foraging in a group and prolonged residence time at foraging sites suggests a possible adaptation of $Z$. auriculata to obtain more resources, proportional to their greater body mass.

According to our analysis, different proportions of herbaceous plants and gramineae, paving, plantations and shrubs comprise the habitats selected by each species and contribute to the differences between them. Columbina talpacoti and C. picui showed a greater similarity in this study both in foraging strategies used and the selected environmental variables, suggesting a greater niche overlap between them. However, C. picui was most frequently observed in large trees, a fact confirmed by PCA analysis, in which C. picui is more dependent on large trees in the environment than C. talpacoti. Ecological overlap was also recorded in species of the Columbina genus in Venezuela, including C. talpacoti, which had a dietary overlap with three other Columbina species (Pérez \& Bulla 2000).

Adapting to anthropic environments without continuous forestation cover can be one of the most influential factors in the selection of habitat by the three Columbidae species studied. Although the type of foraging used by the three species throughout the year was basically the same, i.e. glean, and even though four of the environmental variables studied were considered common to the selected habitats, it is possible for the three species of Columbidae to coexist in the study region. Other factors not analyzed in this study might also be relevant to the survival of each species. However, important features of the physical environment and vegetation structure that comprised the habitat of each species were defined. The differences found in the habitat selected by each species, the different time spent at foraging sites and the different substrates used in foraging are results that contribute to the coexistence of C. talpacoti, C. picui and Z. auriculata and promote ecological partitioning of these similar species.

It is further relevant that $Z$. auriculata demonstrates a wide ecological range because of its ability to inhabit different environments occupied by humans and maintain a large number of individuals at these sites; management practice for this species should therefore consider human activity, reflecting the influence of the explosion in human population.

\section{Acknowledgments}

We thank Luiz dos Anjos for the contributions during this research and for advice. Edson Lopes helped us to improve a version of the manuscript and the technicians of the Museum of Zoology at UEL Aparecido and Edson helped in sampling. We thank local families Mrs. Luiza, Sir Otacílio, Mrs. Maria Helena, Sir Guilon and the Programa de Pós-graduação for academic and financial support.

\section{References}

ALTMANN, J. 1974. Observational study of behavior: Sampling methods. Behaviour. 49(3-4):227-265. PMid:4597405. http://dx.doi. org/10.1163/156853974X00534

BAPTISTA, L.F., TRAIL, P.W. \& HORBLIT, H.M. 1997. Family Columbidae (pigeons and doves). In Handbook of the Birds of the World. Volume 4: Sandgrouse to Cuckoos (J. del Hoyo, A. Elliott \& J. Sargatal, eds.). Lynx Edicions, Barcelona, p.60-243.

BEDNEKOFF, P.A. \& LIMA, S.L. 2005. Testing for peripheral vigilance: do birds value what they see when not overly vigilant? Anim. Behav. 69:1165-1171. http://dx.doi.org/10.1016/j.anbehav.2004.07.020

BEGON, M., TOWSEND, C.R. \& HARPER, J.L. 2006. Ecology: From Individuals to Ecosystems. Blackwell, Oxford.

BEISSINGER, S.R. \& OSBORNE, D.R. 1982. Effects of urbanization on avian community organization. Condor. 84:75-83. http://dx.doi. org $/ 10.2307 / 1367825$

BLOCK, W.M. \& BRENNAN, L.A.. 1993. The habitat concept in ornithology: Theory and applications. Current Ornithol. 11:35-91. http://dx.doi. org/10.1007/978-1-4757-9912-5_2

BUCHER, E.H. \& BOCCO, P.J. 2009. Reassessing the importance of granivorous pigeons as massive, long-distance seed dispersers. Ecology. 90(8): 2321-2327. PMid:19739393. http://dx.doi.org/10.1890/08-2077.1 
BUCHER, E.H. \& RANVAUD, R.D. 2006. Eared dove outbreaks in South America: patterns and characteristics. Acta Zool. Sinica. 52:564-567.

BURGER, J. 1992. Drinking, Vigilance, and Group Size in White-Tipped Doves and Common Ground-Doves in Costa Rica. Wilson Bull. 104(2):357-359

CÂNDIDO-JUNIOR, J.F., SNAK, C., CASTALDELLI, A.P.A., BROCARDO, C.R. \& MODEL, K.J. 2008. Dieta de avoantes (Zenaida auriculata DesMurs, 1847) atropeladas na BR-277 entre Cascavel e Foz do IguaçuPR e implicações para seu manejo. Rev. Bras. Biociênc. 6(1):68-69.

CHACÍN, M. \& CALCHI, R. 2007. Dieta de la Paloma Sabanera (Zenaida auriculata) em el Noroeste de Venezuela durante la temporada de caza 2001. Bol. Cent. Investig. Biol. Univ. Zulia. 41(3):340-349.

CINTRA, R., ALVES, M.A.S. \& CAVALCANTI, R.B. 1990. Dieta da Rolinha Columbina talpacoti (Aves, Columbidae) no Brasil Central - comparação entre sexos e idades. Rev. Bras. Biol. 50(2):469-473.

CUETO, V.R. \& CASENAVE, J.L. 2002. Foraging behavior and microhabitat use of birds inhabiting coastal woodlands in Eastcentral Argentina. Wilson Bull. 114(3):342-348. http://dx.doi.org/10.1676/00435643(2002)114[0342:FBAMUO]2.0.CO;2

DUNNING, J.B. 2008. CRC handbook of avian body masses. 2nd ed. CRC Press, Florida.

ERWIN, R.M. 1983. Feeding habitats of nesting wading birds: spatial use and social influences. The Auk. 100(4):960-970.

FUNDAÇÃO SOS MATA ATLÂNTICA \& INSTITUTO NACIONAL DE PESQUISAS ESPACIAIS - INPE. 2009. Atlas dos remanescentes florestais da Mata Atlântica - Período 2005-2008. http://www.inpe.br/ (último acesso em 16/04/2013).

GONZÁLEZ, J.A. 1997. Seasonal variation in the foraging ecology of the wood stork in the Southern Llanos of Venezuela. The Condor. 99:671680. http://dx.doi.org/10.2307/1370479

HEJL, S.J., VERNER, J. \& BELL, G.W. 1990. Sequential versus initial observations in studies of avian foraging. In Avian Foraging: Theory, Methodology and Applications (M.L. Morrison, C.J Ralph, J. Verner \& J.R. Jehl Jr., eds.). Cooper Ornithological Society, Berkeley, v.13, p.166-173.

HUTTO, R.L. 1985. Habitat selection by nonbreeding, migratory land birds. In Habitat Selection in Birds (M.L. Cody, ed.). Academic Press, New York, p.455-476.

INSTITUTO AGRONÔMICO DO PARANÁ - IAPAR. 2013. Médias Históricas do Município de Londrina. http://www.iapar.br/arquivos/ Image/monitoramento/Medias_Historicas/Londrina.htm (último acesso em 16/04/2013).

JONES, J. 2001. Habitat selection studies in Avian Ecology: A critical review. The Auk. 118(2):557-562.

KREBS, C.J. 1985. Ecology: The Experimental Analysis of Distribution and Abundance. Harper and Row, New York.

KUSHLAN, J. A. 1981. Resource use strategies of wading birds. Wilson Bull. 93(2):145-163.
LOPES, E.V. \& ANJOS, L. 2006. A composição da avifauna do campus da Universidade Estadual de Londrina, norte do Paraná, Brasil. Rev. Bras. Zool. 23(1):145-156. http://dx.doi.org/10.1590/S010181752006000100006

LOPES, E.V., VOLPATO, G.H., MENDONÇA, L.B., FÁVARO, F.L. \& ANJOS, L. 2006. Abundância, micro-habitat e repartição ecológica de papa-formigas (Passeriformes, Thamnophilidae) na bacia hidrográfica do rio Tibagi, Paraná, Brasil. Rev. Bras. Zool. 23(2):395-403. http://dx.doi. org/10.1590/S0101-81752006000200013

MACARTHUR, R. \& LEVINS, R. 1964. Competition, habitat selection, and character displacement in a patchy environment. Proc. Nat. Acad. Sci. 51:1207-1210. PMid:14215645 PMCid:PMC300237. http://dx.doi. org/10.1073/pnas.51.6.1207

MARRA, P.P. \& REMSEN J.V.J. 1997. Insight into the maintenance of high species diversity in the neotropics: habitat selection and foraging behavior in understory birds of tropical and temperate forests. Ornithol. Monogr. 48:445-483. http://dx.doi.org/10.2307/40157547

MILESI, F.A., CASENAVE, J.L. \& CUETO, V.R. 2008. Selection of foraging sites by desert granivorous birds: vegetation structure, seed availability, species-specific foraging tactics, and spatial scale. The Auk. 125(2):473484. http://dx.doi.org/10.1525/auk.2008.07085

MURTON, R.K., BUCHER, E.H., NORES, M., GOMEZ, E. \& REARTES, L. 1974. The ecology of the eared dove (Zenaida auriculata) in Argentina. Condor. 76: 80-81. http://dx.doi.org/10.2307/1365986

PÉREZ, E.M. \& BULLA, L. 2000. Dietary relationships among four granivorous doves in Venezuelan savannas. J. Trop. Ecol. 16(6):865-882. http://dx.doi.org/10.1017/S0266467400001772

RANVAUD, R.D. \& BUCHER, E.H. 2006. Explosion of eared dove: the unique case in southeast Brazil. Acta Zool. Sinica. 52: 568-569.

RANVAUD, R., FREITAS, K.C., BUCHER, E.H., DIAS, H.S., AVANZO, V.C. \& ALBERTS, C.C. 2001. Diet of eared doves (Zenaida auriculata, Aves, Columbidae) in a sugar-cane colony in Southeastern Brazil. Braz. J. Biol. 61(4):651-660. PMid:12071322. http://dx.doi.org/10.1590/ S1519-69842001000400015

REMSEN, J.V. \& ROBINSON, S.K. 1990. A classification scheme for foraging behavior in terrestrial habitat in studies of avian foraging. In Avian Foraging: Theory, Methodology and Applications (M.L. Morrison, C.J Ralph, J.Verner \& J.R. Jehl Jr., eds.). Cooper Ornithological Society, Berkeley. v 13, p. 144-160.

SICK, H. 1997. Ornitologia brasileira. Edição revista e ampliada por J.F. Pacheco. Nova Fronteira, Rio de Janeiro.

SKUTCH, A.F. 1964. Life histories of Central American Pigeons. Wilson Bull. 76(3): 211-247.

VOLPATO, G.H. \& ANJOS, L. 2001. Análise das estratégias de forrageamento das aves que se alimentam no solo na Universidade Estadual de Londrina, Estado do Paraná. Ararajuba. 9(2):95-99.

WESTCOTT, P.W., MARIÑO, H.F. \& ANJOS, L. 2002. Observando aves em Londrina: norte do Paraná - Brasil. EdUEL, Londrina.

WIENS, J.A. 1989. The Ecology of Bird Communities. University Press, Cambridge, v.1-2. http://dx.doi.org/10.1017/CBO9780511608568 